\title{
Application of satellite data in the quantitative assessment of evapotranspiration in northeastern Poland
}

\author{
Daniel ZASZEWSKI ${ }^{1, *}$, Tomasz GRUSZCZYŃSKI ${ }^{1}$ and Jerzy J. MAŁECKI ${ }^{1}$ \\ 1 University of Warsaw, Faculty of Geology, Żwirki i Wigury 93, 02-089 Warszawa, Poland
}

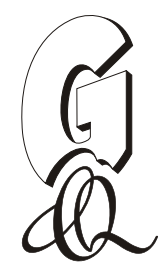

Zaszewski, D., Gruszczyński, T., Małecki, J., 2020. Application of satellite data in the quantitative assessment of evapotranspiration in northeastern Poland. Geological Quarterly, 64 (3): 766-780, doi: 10.7306/gq.1553

Associate Editor: Tatiana Solovey

We describe a method of calculating one of the basic phenomena influenced by groundwater recharge, namely evapotranspiration $(E T)$. The Operational Simplified Surface Energy Balance (SSEBop) algorithm was applied to calculate actual evapotranspiration $\left(E T_{a}\right)$, being modified to include spatiotemporal changes of substrate humidity and so referred to as mSSSEBop. Calculations were performed within the Szkwa and Rozoga River catchments (NE Poland). Quantitative $E T_{a}$ assessment was based on the analysis of Landsat satellite images, hydrometeorological and hydrogeological data. The results obtained for the original SSEBop algorithm and the modified mSSEBop one were compared with the water balance and data from a MOD16A2 dataset. The calculated water balance gave $E T_{a}$ values close to results using mSSEBop (with differences of 9-54 mm/year). In the case of the original algorithm, differences were in range of $42-218 \mathrm{~mm} /$ year. When compared with MOD16A2 data, the differences were within the range of -16.7 to $23.2 \mathrm{~mm} / 8$ days, with the mSSEBop algorithm giving on average lower $E T_{a}$ sums $(\sim 14 \%)$ than MOD16A2 while SSEBop gave results higher than MOD16A2 by $\sim 12 \%$. The studies performed indicate that the method presented, using satellite data, gives a reliable, spatial and temporal $E T_{a}$ assessment for the mid latitudes.

Key words: evapotranspiration, remote sensing, Landsat, SSEBop, MOD16A2, Kurpie Sandur (Poland).

\section{INTRODUCTION}

Groundwater recharge estimations on a regional scale require access to sets of scattered input data. One of the basic phenomena that influences groundwater recharge (beside precipitation) is evapotranspiration $(E T)$. So far, investigations have shown that loss related with ET may reach $60-70 \%$ of precipitation values.

The process of evaporating water into the atmosphere under given meteorological conditions, the amount and nature of vegetation and currently available soil water resources is called evapotranspiration $\left(E T_{a}\right)$. $E T_{a}$ also includes the evaporation of water retained on plants as a result of interception (Soczyńska, 1989; Dąbrowska-Zielińska, 1995). An important concept used in this article is the term potential evapotranspiration $\left(E T_{p}\right)$, i.e. the amount of water that could evaporate and transpire from a vegetated landscape without restrictions other than the atmospheric demand (Lu et al., 2005; WMO, 2008). To simulate potential evaporation and transpiration processes, an ET estimation method was used for a reference surface $\left(E T_{0}\right)$, defined as

\footnotetext{
* Corresponding author, e-mail: danielzaszewski@uw.edu.pl
}

Received: January 29, 2020; accepted: May 8, 2020; first published online: August 31, 2020 the rate at which readily available soil water is discharged into the atmosphere from a surface covered with a specific type of vegetation (Jensen et al., 1990).

$E T_{a}$ is a process difficult for quantitative assessment, particularly on a regional scale. Methods of direct $E T_{a}$ measurements, such as lysimeters, Energy Balance Bowen Ratio stations, Eddy Covariance flux towers, or indirect methods using scintillometers enable data to be obtained at a range from several metres to $\sim 1$ $\mathrm{km}$. The large spatial variability of $E T_{a}$ means that the application of point measurements in regional investigations can generate results of high uncertainty. Hence, the acquisition of high-quality spatially distributed hydrological information is one of the main goals in hydrogeological investigations.

The development and promotion of remote sensing techniques and the wide accessibility of satellite images allows fast and inexpensive analysis of natural phenomena. Remote sensing is the basis of environmental monitoring in many parts of the world where amounts of field data are insufficient. Moreover, satellite data, contrary to traditional point surface observations, are spatial in character; therefore, in their case, interpolation and extrapolation procedures do not have to be applied. Procedures enabling $E T_{a}$ assessment with the application of remote sensing use measurements of electromagnetic radiation in the near, mid and thermal infrared.

Analysis of $E T$ quantitative characteristics is performed indirectly through a combination of remote sensing techniques with geographic information systems (GIS), ground meteorological 
measurements and hydrological observations. However, optical scanners used in environmental analyses are sensitive to unfavourable atmospheric conditions (clouding, fogging, snow cover). In combination with the relatively low frequency of high-resolution satellite revisits, this means that applications of such databases in hydrological analysis of areas of temperate climate are not common.

This situation encouraged the authors to perform their own analyses focused on assessing the possibility of using remote sensing in $E T_{a}$ determination for areas located in mid latitudes. The present study includes the design of a calculation procedure that enables the obtaining of information regarding the seasonal variability of factors determining $E T_{a}$ from instantaneous values of variables characterising the natural environment, acquired from remote sensing techniques.

The methodology described uses Landsat satellite data and includes variable climate conditions, land coverage and use and geological and hydrological characteristics. These datasets were used in an algorithm for evapotranspiration assessment the Operational Simplified Surface Energy Balance (SSEBop).

The original SSEBop model is dedicated to analyses conducted on a regional scale. In general, it consists of scaling potential evapotranspiration (calculated via the Penman-Monteith formula $-E T_{0}$ ) using a factor calculated with satellite data. Previous studies have shown a high accuracy of $E T_{a}$ values obtained with SSEBop. Comparison of SSEBop results with point observations, carried out using the eddy covariance method, in the case of low-resolution MODIS sensor data, showed a match of $R^{2}=0.64-0.86$. Studies conducted with the use of Landsat satellite data were characterized by a match of $R^{2}=0.9-0.94$. Verification based on the water balance for the Colorado River basin showed a match of $R^{2}=0.74$. The big advantage of the SSEBop model is the relatively small amount of input data necessary for calculations. However, it does not take into account soil moisture, which has a huge impact on quantitative changes in evapotranspiration.

A key phase in the assessment of seasonal evapotranspiration is determining the $E T_{a}$ values between sets of images from satellite revisits. In the case of areas characterised by weather conditions allowing the frequent acquisition of such images, evapotranspiration calculations may take place with the application of temporal distributions of $E T_{0}$. Potential $E T$ values are insufficient in conditions of low and non-uniform access to satellite images and may lead to significant overestimation of the results obtained.

In order to eliminate this factor, the authors introduced modified formulas of the seasonal $E T_{a}$ estimation (mSSEBop), which include changes in soil moisture over time. Assessment of calculation results was based on their comparison with results obtained using water balance and evapotranspiration data from the MODIS (Moderate Resolution Imaging Spectroradiometer) mission.

\section{MATERIALS AND METHODS}

\section{STUDY AREA}

The investigations were performed in NE Poland in the catchments of two neighbouring rivers, the Szkwa and Rozoga (Fig. 1A, B), flowing through the Kurpie Sandur. The analysis was made for an interval encompassing three hydrological years: 2014-2016. The catchments of both rivers have similar areas, of $466 \mathrm{~km}^{2}$ for the Szkwa and $481 \mathrm{~km}^{2}$ for the Rozoga. Both rivers are tributaries of the Narew River.
The study area is lightly urbanised. The dominant types of land coverage are forests (36\% of the whole area; Fig. 1C). These are dominated by coniferous communities $(>27 \%)$, whereas mixed and broad-leaved forests are less common (9\%). Permanent grasslands, i.e. meadows and pastures, cover $\sim 33 \%$ of the surface area. A considerable part of the study area is occupied by farmlands $(27 \%)$, dominated by arable land $(22 \%)$. Surface water reservoirs, wetlands and peat bogs cover $<1 \%$ of the surface area. Information regarding the land cover was taken from the Corine Land Cover database for Poland, compiled in 2012 (CLC2012).

The area analysed area is influenced by a temperate climate, at the boundary between two air masses with differing thermal and humidity properties: humid from the north Atlantic (mainly polar-marine) and dry from Eastern Europe and Asia (polar-continental). This results in a large variability of atmospheric conditions in particular seasons and a large number of cloudy days (averagely 120-150 days/year). The years analysed were much warmer than the mean air temperature over the multiannual period 1972-2016. The mean air temperature was higher by $\sim 1.1-1.5^{\circ} \mathrm{C}$ than the long-term average $\left(7.4^{\circ} \mathrm{C}\right)$.

The distribution of average monthly precipitation in the average annual sum of precipitation indicates its continental character (summer maximum and winter minimum). This is, however, modified by the influence of an oceanic precipitation regime (prevalence of autumn precipitation above spring precipitation), which results in a mixed, continental-oceanic character of the annual rhythm of precipitation. The study interval was preceded by a year in which the total annual precipitation exceeded the mean values from the multiannual interval 1972-2016, reaching $754-912 \mathrm{~mm}$. The hydrological years 2014 and 2015 may be treated as dry intervals. In 2014 the total annual precipitation was within 533-676 mm (Fig. 2A, B). Year 2015 was characterised by an even lower annual precipitation (between 512-658 mm). In 2016 a large increase in annual precipitation was observed, up to $800-931 \mathrm{~mm}$.

Deposits of the Kurpie Sandur in the study area are represented mainly by fluvioglacial sands and gravels (Fig. 1B). The thickness of fluvioglacial deposits is variable, usually from 10 to $30 \mathrm{~m}$, although in some cases deposits of the Kurpie Sandur form combined successions with older deposits of fluvioglacial origin, reaching $60-80 \mathrm{~m}$ in thickness. The dip of the plain is generally constant, consistently to the SE. Differences in altitude between the northern and southern margins of the sandur reach $\sim 40 \mathrm{~m}$, with altitudes from $145 \mathrm{~m}$ a.s.I. in the north to $\sim 110 \mathrm{~m}$ a.s.l. in the south. Characteristic elements of the Kurpie Sandur are inactive dunes. In the study area these are dominated by parabolic dunes, usually in groups of parabolas and ridges from $2 \mathrm{~m}$ to $20 \mathrm{~m}$ high.

To assess the retention changes in the catchments studied, hydrogeological conditions in the shallow aquifer were assessed. The shape of the water table of this aquifer is related to topography. The main groundwater drainage axis is the Narew River. The Szkwa and Rozoga River valleys act as a minor groundwater drainage base. In most of the area, groundwater occurs in fluvioglacial and fluvial sands, and sands with gravel. The permeability of the outwash aquifer perceptibly decreases from the north to the south.

Climatic (especially precipitation and evapotranspiration) and hydrogeological conditions were the dominant influence on the river runoff. The values of the annual outflow from the catchment, recalculated to mm of water column, in 2014-2016 was in the range of 88 to $128 \mathrm{~mm}$ for the Szkwa and 90 to $116 \mathrm{~mm}$ for the Rozoga River. 


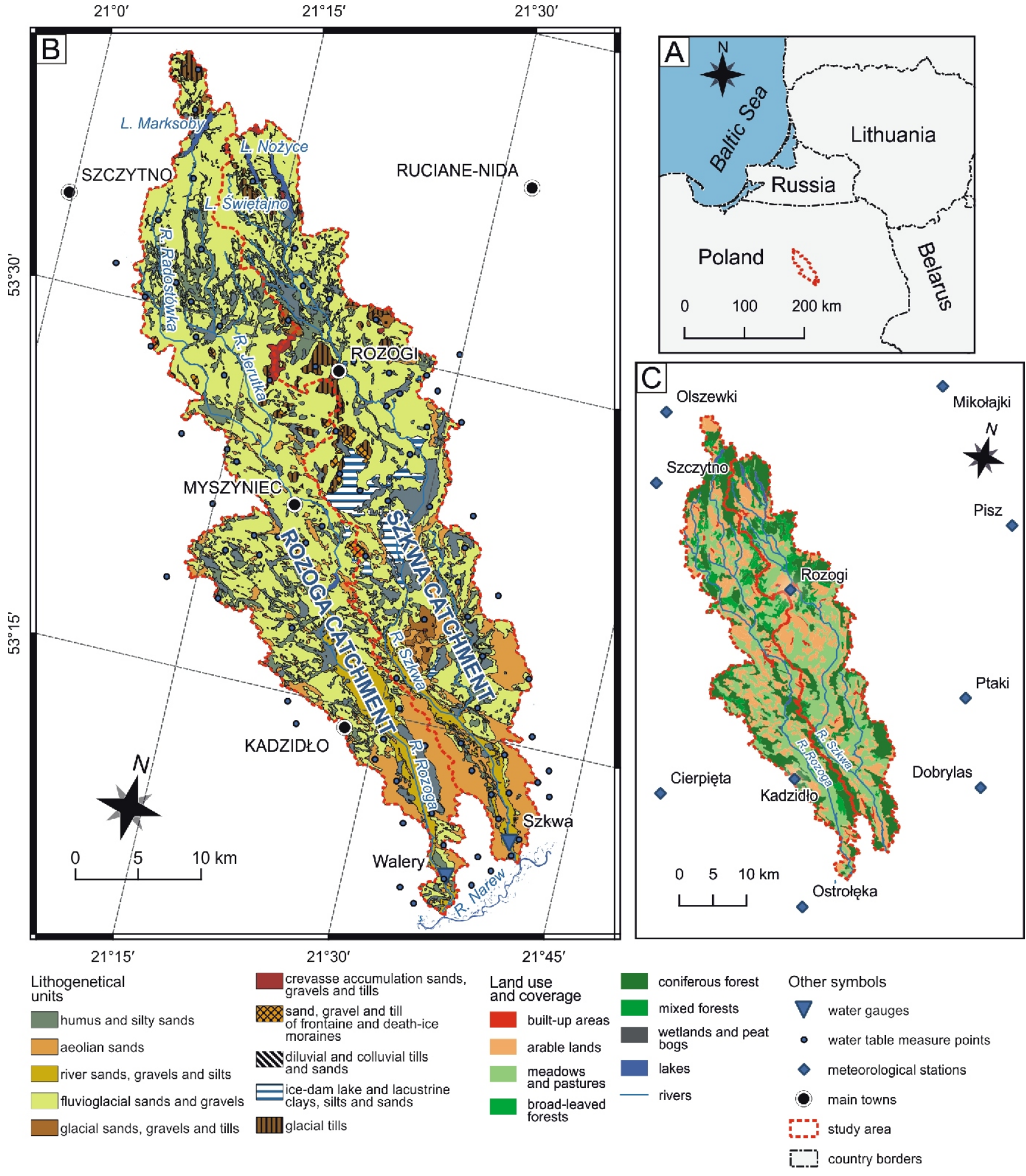

Fig. 1A - location; B - surface lithology (based on vector GIS layers of the Detailed Geological Map of Poland); C - land use and coverage of the study area (information on land coverage was taken from the Corine Land Cover database for Poland, compiled in 2012 - CLC2012)

Project CLC2012 was realised by the Institute of Geodesy and Cartography, and financed by EU resources; this data can be downloaded from the website: http://clc.gios.gov.pl/ 
A

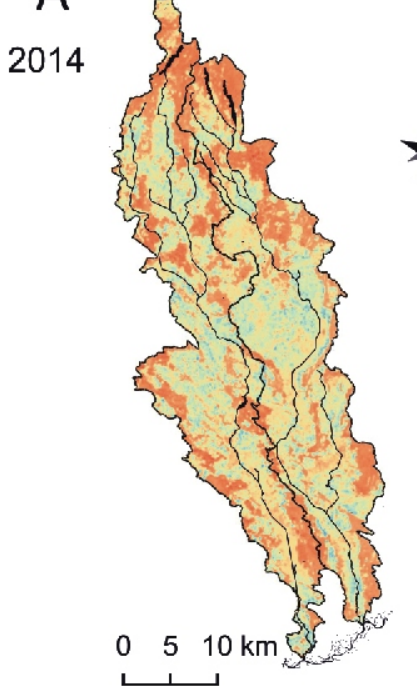

Average $E T_{f r}(-)$

$\square<0.2 \square 0.2-0.4 \square$
2015

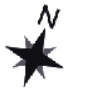

2015

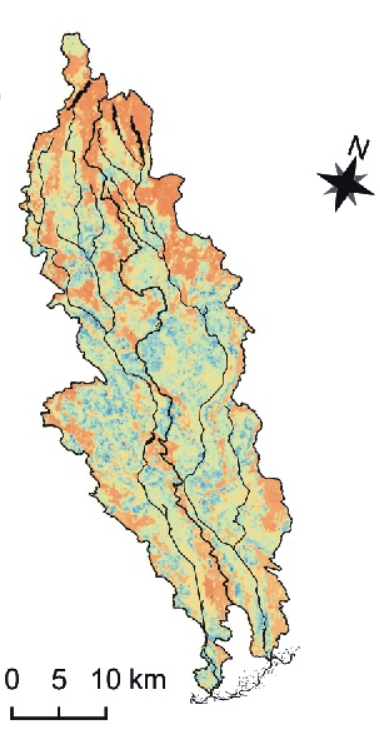

$0.4-0.6 \square$

$0.6-0.8 \square$

$0.8-1.0$

$>1.0$

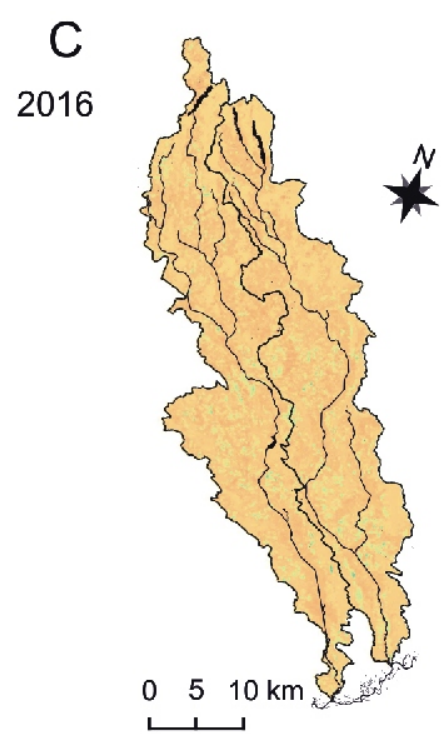

Other symbols

catchments $\square$ lakes - rivers

Fig. 2. Average values of the evapotranspiration fraction $E T_{f r}$ in hydrological years 2014-2016

\section{LANDSAT DATA}

Images gained from radiometric instruments of the Landsat 7 and 8 satellites were used in the calculations. The ranges of spectra channels gained by the OLI and TIRS (Landsat 8) and ETM+ (Landsat 7) scanners are similar, which allows for their joint analysis. Moreover, application of Landsat 7 and 8 satellites allows the obtaining of images every 8 days. Spatial resolution of particular images is within the range of 30-120 m.

Ideal satellite images should not contain elements disrupting the signal flow from Earth's surface to a receiver mounted on a satellite. In mid latitudes, the signal reflected from the land's surface is disrupted by clouds and their shadows. Radiometric and atmospheric correction in ReSe ATCOR 2 software was applied to limit the influence of these factors. This allowed a significant increase in satellite data quality. The correction facilitated recovery of part of the information that was distorted by the presence of water vapour and thin cirrus clouds.

The study area is located in one scene of Landsat data with the following coordinates: WRS-2 Path: 188, Row: 23. Images with a low presence of disturbing elements (clouds or their shadows) were selected for the analyses. 24-image sets were selected from the three hydrological years analysed (Table 1). The temporal distribution of selected sets was not even. The most numerous ones were obtained from the spring-summer months, being also intervals in which the intensity of evapotranspiration is the highest and most strongly linked with plant vegetation conditions.

\section{GROUND OBSERVATION DATA}

The calculation procedure described required acquisition of data characterising the atmospheric state. Variables describing atmospheric conditions which were used in the calculations included: mean daily air temperature $\left(T_{a}\right)$, maximum daily air temperature $\left(T_{\max }\right)$, minimum daily air temperature $\left(T_{\min }\right)$, mean daily dew point $\left(T_{\text {dew }}\right)$, mean daily air pressure $\left(P_{\text {atm }}\right)$, mean daily wind speed $\left(u_{2}\right)$, daily value of insolation $(n)$ and daily sum of precipitation $(P)$. The accumulated data were taken from the database of the Institute of Meteorology and Water Management - National Research Institute (IMGW-PIB). Data from 10 observation points were acquired (Fig. 1C and Table 2).

$P$ values measured using a Hellman's rain gauge are usually underestimated in relation to actual precipitation. Because of this, precipitation values collected from IMGW-PIB sites were corrected using empirical formulas proposed by Jaworski (2004). The formula dedicated to the correction of rainfall value has the form:

$$
P_{\text {kor. }}=1.135 \times(P+1)^{0.165}+P+k_{1}-1 \text { for } P \in\langle 0.1 ; 41.9 \mathrm{~mm}[1]
$$

In the case of snowfall, the formula is as follows:

$$
P_{\text {kor. }}=1.167 \times P+0.29+k_{1}
$$

In both formulas $P_{\text {kor. }}$ corresponds to corrected values of precipitation $(\mathrm{mm}), k_{1}$ is a coefficient describing loss caused by dampening of the rain gauge.

$$
\text { Table } 1
$$

Landsat 7 (L7) and Landsat 8 (L8) images used in the report

\begin{tabular}{|l|l|l|}
\hline Year 2014 & Year 2015 & Year 2016 \\
\hline $11.11(\mathrm{~L} 8)$ & $22.03(\mathrm{~L} 8)$ & \\
$23.02(\mathrm{~L} 7)$ & $23.04(\mathrm{~L} 8)$ & $25.11(\mathrm{~L} 7)$ \\
$11.03(\mathrm{~L} 7)$ & $02.06(\mathrm{~L} 7)$ & $24.03(\mathrm{~L} 8)$ \\
$04.04(\mathrm{~L} 8)$ & $10.06(\mathrm{~L} 8)$ & $19.05(\mathrm{~L} 7)$ \\
$06.05(\mathrm{~L} 8)$ & $04.07(\mathrm{~L} 7)$ & $04.06(\mathrm{~L} 7)$ \\
$22.05(\mathrm{~L} 8)$ & $05.08(\mathrm{~L} 7)$ & $23.08(\mathrm{~L} 7)$ \\
$07.06(\mathrm{~L} 8)$ & $13.08(\mathrm{~L} 8)$ & $08.09(\mathrm{~L} 7)$ \\
$09.07(\mathrm{~L} 8)$ & $08.10(\mathrm{~L} 7)$ & $16.09(\mathrm{~L} 8)$ \\
$29.10(\mathrm{~L} 8)$ & & \\
\hline
\end{tabular}


Meteorological data used in the study

\begin{tabular}{|l|c|c|c|}
\hline \multicolumn{1}{|c|}{ Station name } & Latitude & Longitude & Observation range \\
\hline Ostrołęka & $53^{\circ} 4^{\prime} 14.1^{\prime \prime} \mathrm{N}$ & $21^{\circ} 32^{\prime} 40.1^{\prime \prime} \mathrm{E}$ & $T_{a}, T_{\max }, T_{\min }, T_{\text {dew }}, P_{\text {atm }}, u_{2}, n, P$ \\
\hline Mikołajki & $53^{\circ} 47^{\prime} 20.9^{\prime \prime} \mathrm{N}$ & $21^{\circ} 35^{\prime} 22.6^{\prime \prime} \mathrm{E}$ & $T_{a}, T_{\max }, T_{\min }, T_{\text {dew }}, P_{\text {atm }}, u_{2}, n, P$ \\
\hline Szczytno & $53^{\circ} 34^{\prime} 36.8^{\prime \prime} \mathrm{N}$ & $21^{\circ} 0^{\prime} 44.1^{\prime \prime} \mathrm{E}$ & $T_{\mathrm{a}}, P$ \\
\hline Rozogi & $53^{\circ} 28^{\prime} 44.6^{\prime \prime} \mathrm{N}$ & $21^{\circ} 21^{\prime} 34.5^{\prime \prime} \mathrm{E}$ & $P$ \\
\hline Kadzidło & $53^{\circ} 14^{\prime} 4.9^{\prime \prime} \mathrm{N}$ & $21^{\circ} 27^{\prime} 49.2^{\prime \prime} \mathrm{E}$ & $P$ \\
\hline Cierpięta & $53^{\circ} 10^{\prime} 31.9^{\prime \prime} \mathrm{N}$ & $21^{\circ} 10^{\prime} 50.5^{\prime \prime} \mathrm{E}$ & $P$ \\
\hline Dobrylas & $53^{\circ} 16^{\prime} 43.2^{\prime \prime} \mathrm{N}$ & $21^{\circ} 52^{\prime} 15.8^{\prime \prime} \mathrm{E}$ & $P$ \\
\hline Ptaki & $53^{\circ} 23^{\prime} 26.0^{\prime \prime} \mathrm{N}$ & $21^{\circ} 47^{\prime} 39.8^{\prime \prime} \mathrm{E}$ & $P$ \\
\hline Pisz & $53^{\circ} 37^{\prime} 44.0^{\prime \prime} \mathrm{N}$ & $21^{\circ} 48^{\prime} 38.5^{\prime \prime} \mathrm{E}$ & $P$ \\
\hline Olszewki & $53^{\circ} 40^{\prime} 19.1^{\prime \prime} \mathrm{N}$ & $20^{\circ} 59^{\prime} 51.0^{\prime \prime} \mathrm{E}$ & \\
\hline
\end{tabular}

The characteristics of total runoff for the Szkwa and Rozoga catchments, used at the verification stage, were elaborated based on mean 24-hour values of discharge $Q$ for the flows analysed, obtained from IMGW-PIB. The catchment surface areas are limited by water gauge cross-sections, situated in Walery village (4.59 km from the mouth of Rozoga River) and in Szkwa village (2.37 km from the mouth of the Szkwa River). The interval for which the data were acquired encompassed the hydrological years 2010-2016.

In order to determine changes in retention in the study area, measurement of the groundwater table was made. Observations of the groundwater table were made in 90 dug wells (Fig. 1B). During the 3-year study interval, 4 measurement sessions took place, in November 2013, October 2014, November 2015 and October 2016.

\section{DESCRIPTION OF THE MODIFIED SSEBop ALGORITHM (mSSEBop)}

Quantitative assessment of actual evapotranspiration $E T_{\text {a }}$ in the study interval was based on a modified version of the SSEBop algorithm (mSSEBop). $E T_{a}$ is the amount of water discharged to the atmosphere in given meteorological and vegetation conditions, as well as presently accessible soil water resources. $E T_{a}$ includes also evaporation water retained by plants due to interception. In contrast to the extensive physical models, the SSEBop model does not include all components of thermal and radiation balance, but defines the functions that limit evapotranspiration under clear sky radiation conditions.

Satellite images used in the SSEBop calculations were made in the spectral ranges for visible light, near and medium infrared, and thermal infrared. After processing and correction, three remote sensing components of the SSEBop algorithm were obtained: NDVI (Normalized Difference Vegetation Index), surface albedo, and surface temperature $\left(T_{\mathrm{s}}\right)$. This dataset allowed for determination of actual radiation conditions, vegetation state and condition, and also the distribution of the potential evapotranspiration in space and time.

An element describing the spatial $E T_{a}$ distribution is the actual evapotranspiration fraction $E T_{f r}$. $E T_{f r}$ expresses the ratio of actual evapotranspiration to the calculated potential evapotranspiration values. It is assumed that the value of $E T_{f r}$, calculated on the basis of satellite images, is constant for an interval characterised by similar meteorological and hydrological conditions, and similar development of vegetation, for the day they were taken. The SSEBop model requires determining the values of warm/dry and cold/humid thermal boundary conditions of $E T$, unique for each image analysed. The link between the $E T_{a}$ model boundaries and actual thermal conditions is expressed by the formula (Senay et al., 2013):

$$
E T_{f r}=\frac{T_{h}-T_{s}}{T_{h}-T_{c}}=\frac{T_{h}-T_{s}}{d T}
$$

where: $T_{s}$ - the land surface temperature (recalculated from Landsat 8 TIRS and Landsat 7 ETM+ sensors) expressed in Kelvin, $T_{h}-$ the calculated value of surface temperature in a given pixel of the image with regard to conditions of lowest $E T$ intensity. $T_{h}$ is given as follows:

$$
T_{h}=T_{c}+d T
$$

$T_{c}$ - the cold boundary of the model, understood as the temperature of the land surface at which $E T_{a}$ attains the highest values:

$$
T_{c}=\left(\frac{T_{s_{-} \text {cold }}}{T_{\max }}\right) \times T_{\max }
$$

where: $T_{s_{-} \text {cold }}-$ the satellite-based surface temperature (in pixels where $N D V I>0.8$ ) and $T_{\max }$ (in $\mathrm{K}$ ) is the corresponding daily maximum air temperature at the same location and period. lows:

The second component of the equation [4] is given as fol-

$$
d T=\frac{R_{n} \times r_{a h}}{\rho_{a} \times C_{p}}
$$

where: $R_{n}$ - the clear sky net radiation in $\mathrm{kJ} \mathrm{m}^{-2} \mathrm{day}^{-1}$ (calculated using standard equations recommended by and satellite data), $C_{p}-$ the specific heat of air at constant pressure $\left(1.013 \mathrm{~kJ} \mathrm{~kg}^{-1} \mathrm{C}^{-1}\right) ; \rho_{a}-$ the density of air, $r_{a h}$ - the aerodynamic resistance to heat flow from a hypothetical bare and dry surface $\left(110 \mathrm{sm}^{-1}\right.$ is recommended by).

Using several images characterising $E T_{f r}$ changes in the time interval analysed, it was possible to subdivide this interval into quasi-uniform sections with individual $E T_{\text {fr }}$ distributions. Next, a cumulative actual evapotranspiration value is determined from each section ( $\left.E T_{\text {a_period }}\right)$ :

$$
E T_{a_{-} \text {period }}=E T_{\text {fr_period }} \times \sum_{1}^{n} E T_{o}
$$


where: $E T_{\text {fr period }}$ - the evapotranspiration fraction $E T_{\text {fr }}$ for the time interval analysed, $E T_{o}$ - daily potential evapotranspiration, and $n-$ the number of days in the time interval analysed.

In the original SSEBop method the Penman-Monteith equation (PM) was used for assessment of the intensity of evaporation and transpiration for the reference surface $\left(E T_{0}\right)$. The modified SSEBop method takes into account the impact of soil moisture changes on evapotranspiration values. Simulation of soil desiccation processes was performed by balancing daily values of $E T_{o}$ and daily sums of precipitation obtained from meteorological stations. In this case, the method proposed by Schulte et al. was applied. Humidity changes were determined by calculating the humidity deficiency ( $S M D)$, which is the amount of water, expressed in millimeters of precipitation, required for supplementing the content of water in soil to a level determined by field water volume $\left(S M D_{\max }\right)$. $S M D$ assessment may be expressed by the following formula:

$$
S M D_{t}=S M D_{t-1}-P_{\text {kor. }}+E T_{d}
$$

where: $S M D_{t}$ and $S M D_{t-1}$ are $S M D$ values on day $t$ and on the preceding day $t-1$.

Calculation of reference evapotranspiration, taking into account changes in soil moisture $\left(E T_{d}\right)$, is performed using the following formula:

$$
E T_{d t}=\left\{\begin{array}{l}
E T_{o_{t}} \text { for } S M D \leq S M D_{c} \\
E t_{o_{t}} \times \frac{S M D_{\max }-S M D_{t-1}}{S M D_{\max }-S M D_{c}} \text { for } S M D>S M D_{c}
\end{array}\right.
$$

where: $S M D_{c}$ - the critical soil moisture deficiency $(\mathrm{mm}$; limit of the SMD value, above which transpiration is reduced)

Evaporation and transpiration conditions attained in the $E T_{d}$ calculations were for surfaces characterised by good permeability. In the case of this assumption, Schulte et al. recommend applying values of $S M D_{\max }=110 \mathrm{~mm}$ and $S M D_{c}=0$

$E T_{d}$ values are substituted into formula 7 in place of $E T_{o}$. Then individual $E T_{\text {a period }}$ values are added up within a hydrological year, which in consequence gives the spatial distribution of evapotranspiration in a given year.

\section{VERIFICATION METHODS}

The results of evapotranspiration calculations, based on the mSSEBop algorithm, were verified by two competing methods. The first was water balance, made for both river catchments analysed. Balance calculations used the following formula:

$$
P=E T+Q_{\text {off }}+\Delta S
$$

in which annual precipitation sums $(P)$ are compensated by aerial evaporation sums $(E T)$, outflow from the balance unit $\left(Q_{\text {off }}\right)$ and retention changes $(\Delta S)$. The area analysed lacks large groundwater intakes. Loss caused by water uptake, compared to loss caused by evapotranspiration, and surface and underground outflow, are negligible. Therefore, balance analyses did not include the component describing groundwater exploitation. Annual corrected precipitation sums $\left(P_{\text {kor. }}\right)$ (mm/year), average for the catchment, were attained as value $P$. An estimate $\Delta S$ assessment was made for the needs of balance analysis based on water table observations. Reten-
$\mathrm{T} a \mathrm{ble} 3$

MOD16A2 data products used in the report

\begin{tabular}{|c|c|c|}
\hline Year 2014 & Year 2015 & Year 2016 \\
\hline $01.11-08.11$ & $14.03-21.03$ & \\
$18.02-25.02$ & $15.04-22.04$ & $21.03-28.03$ \\
$06.03-13.03$ & $02.06-09.06$ & $24.05-31.08$ \\
$30.03-06.04$ & $10.06-17.06$ & $01.06-08.06$ \\
$01.05-08.05$ & $26.06-03.07$ & $20.08-27.08$ \\
$17.05-24.05$ & $05.08-12.08$ & $05.09-12.09$ \\
$02.06-09.06$ & $13.08-20.08$ & $13.09-20.09$ \\
$04.07-11.07$ & $08.10-15.10$ & \\
$24.10-31.10$ & & \\
\hline
\end{tabular}

tion values were obtained by multiplying the mean, for the balance area, value of differences in the position of the groundwater table (between the beginning and the end of each year; $\Delta h$ ) and the specific yield $(\mu)$.

Calculations of the catchment water balance allow assessment of the aerial mean of $E T_{a}$ values, but do not give the basis for assessment of the spatial variability of this variable. Therefore, verification of the mSSEBop model results exclusively based on hydrological balance is not complete. $E T_{a}$ values calculated using the methods proposed were compared with data obtained from the model generating spatial and temporal distributions of actual ET - MOD16A2.

MOD16A2 is a product using satellite data acquired from the MODIS sensor. This sensor is installed on two environmental satellites, Terra and Aqua. Both satellites operate in the NASA EOS (Earth Observing System) programme. The relatively low spatial resolution $-500 \mathrm{~m}$ (compared to Landsat data used in mSSEBop - $30 \mathrm{~m}$ ) is compensated by high temporal resolution, which allows determination, in favourable atmospheric conditions, of 8-day $E T_{a}$ sums.

The 8-day $E T_{a}$ sums from the MOD16A2 model did not allow for continuous coverage of the calculation intervals. This is caused (as with Landsat) by the sensitivity of the applied MODIS satellite data to unfavourable climate conditions. MOD16A2 data, the time range of which encompassed or was close to the date of the Landsat images acquired, were used for comparison (Table 3). Next, the $E T_{a}$ value was calculated for the same intervals using the mSSEBop algorithm. The second stage of accommodating data to the comparative analysis was unification of the image pixel spatial resolution. $E T_{a}$ was calculated with application of Landsat images, which were converted from $30 \mathrm{~m}$ resolution to MOD16A2 resolution according to the flux aggregation procedure. Values of $E T_{a}$ from SSEBop were averaged within a MOD16A2 pixel using geoprocessing tools in Esri ArcGIS software.

In order to compare the differences in $E T_{a}$ values for particular forms of land coverage, each pixel in both datasets was attributed to a land coverage and land use class according to the CLC2012 subdivision. The quantitative assessment of differences between mSSEBop and MOD16A2 was based on the mean bias error (MBE) analysis between $E T_{a}$ values from the MOD16A2 dataset and those calculated with the use of the mSSEBop algorithm.

The results obtained by the mSSEBop method were compared with values returned by the original SSEBop algorithm. This allowed determination of the impact of the modification on the calculation outputs. 


\section{RESULTS}

The sets of satellite images acquired, with results of meteorological measurements for the day of acquisition, were used to calculate the evapotranspiration fraction $\left(E T_{f r}\right)$. The results point to spatial and temporal $E T_{f r}$ variability (Figs. 2 and $3 C$ ). The lowest $E T_{\text {fr }}$ values were noted in autumn-winter and in early spring. The mean values for the entire study area were from 0.55 to 0.78 . The highest $E T_{f r}$ values were obtained for images acquired in spring-summer (generally May and June). Mean $E T_{\text {fr }}$ values for the study area attained were from 0.88 to 0.99. The largest contrasts in the spatial $E T_{\text {fr }}$ distribution were obtained for hydrological years 2014 and 2015 (Fig. 2A, B). Woodlands had distinctly higher $E T_{f r}$ values in comparison to meadow and farmland areas (with a mean from 0.8 to 1.1). Such spatial variability was not observed in 2016 (Fig. 3C). The mean $E T_{f r}$ values, in this year, were in the range of $0.8-1.0$.

Instantaneous $E T_{\text {fr }}$ values allow for interpretation of seasonal variability of evapotranspiration, even with a limited number of satellite images. This is particularly clearly visible in the case of curves showing the mean $E T_{f r}$ for agrocoenoses with shallow root systems, sensitive to soil humidity levels (Fig. 3C). Hydrological years 2014 and 2015, during which water deficiencies for crop use occurred, were characterised by lower $E T_{f r}$ values. Abundance of water in 2016 caused increased evapotranspiration from plants and the geological basement, which resulted in higher $E T_{f r}$ values. A more even $E T_{f r}$ was obtained in 2016 both for natural and anthropogenic habitats. This was caused by technical (application of images mainly from the vegetation period) and natural factors (stable and optimal access to water by plants).

Calculation of periodic sums of actual evapotranspiration required assessing 24-hour values of potential evapotranspiration. In the original SSEBop algorithm, potential evapotranspiration is calculated for the grass reference surface $\left(E T_{o}\right)$ using the Penman-Monteith method. The mSSEBop adapts $E T_{o}$ values to soil moisture content $\left(E T_{d}\right)$. The calculations performed have indicated a distinct difference between $E T_{d}$ and $E T_{o}$, which took place in 2014 and 2015 (Fig. 3A, B). For synoptic stations located nearest to the study area (Ostrołęka and Mikołajki), these differences were: $312 \mathrm{~mm} /$ year (2014) and $385 \mathrm{~mm} /$ year (2015) for Ostrołęka and $205 \mathrm{~mm} /$ year (2014) and 223 mm/year (2015) for Mikołajki. The largest differences were observed in summer and autumn seasons, characterised by low sums of precipitation. During the humid year 2016 the calculated differences were much smaller (from $>10$ to $\sim 100 \mathrm{~mm} /$ year).

The intervals between Landsat images that could be used in the analysis were uneven (Fig. $3 \mathrm{C}$ ). The longest were established for late autumn, winter and early spring months. A larger frequency of satellite data obtained for the spring and summer months resulted in briefer duration of the calculation intervals, which allowed for more precise assessment of evaporation and transpiration. The intensity of evapotranspiration in the summer half-year was much higher than in winter. Therefore, despite much longer calculation intervals adopted for autumn and winter, the impact of the $E T_{a}$ value in the winter half-year on the total value of annual evapotranspiration was relatively small.

The datasets obtained, with a spatial distribution of corrected $E T_{o}$ sums in calculation periods $\left(E T_{d \_p e r i o d}\right)$, were multiplied by the assigned tables describing $E T_{f r}$ distribution. Summing of all results within temporal compartments corresponding to particular hydrological years allowed the spatial distribution of annual $E T_{a}$ in the study area to be obtained (Fig. 4).

Annual sums of evapotranspiration for the study area in 2014 and 2015 were $467 \mathrm{~mm} /$ year and $479.5 \mathrm{~mm} /$ year, respec- tively. $E T_{a}$ calculated in 2016 by mSSEBop was larger by $24 \%$ from the average (for the entire area) $E T_{a}$, estimated in 2014 and 2015. The largest similarity of $E T_{a}$ spatial distribution was calculated for 2014 and 2015. Maximum values in the annual $E T_{a}$ were indicated for areas overgrown by forest communities. Annual sums for forests in 2014 and 2015 were 529 and $523 \mathrm{~mm} /$ year. High $E T_{\mathrm{a}}$ values were observed for wetlands, where they reached 501 (2014) and $514 \mathrm{~mm}$ (2015). Much lower annual $E T_{a}$ values were noted for farmlands. Results obtained for 2014 were on average at $441 \mathrm{~mm} /$ year (arable lands), $464 \mathrm{~mm} /$ year (meadows and pastures), $434 \mathrm{~mm} /$ year (complex tillage systems), and $472 \mathrm{~mm} /$ year (areas with a prevalence of farming). Values for 2015 were lower in comparison to the previous year by: 68 (arable lands), 46 (meadows and pastures), 50 (complex tillage systems) and 54 (areas with a prevalence of farming) $\mathrm{mm} /$ year.

In 2016, high $E T_{a}$ values were obtained for meadows and pastures located in river valleys. In 2014 and 2015, increased values of $E T_{a}$ were observed for these communities, but they did not dominate above the neighbouring woodland areas. Annual $E T_{\text {a }}$ sums for meadows and pastures were similar to those of forests and bushes (about $630 \mathrm{~mm} /$ year). Higher $E T_{a}$ values were observed only for wetlands (spatial mean - $647 \mathrm{~mm} / \mathrm{year}$ ). Arable lands, complex tillage systems and areas with a prevalence of farming showed evaporation rates of $608 \mathrm{~mm} /$ year on average.

\section{DISCUSSION}

The credibility of the mSSEBop method was assessed based on a comparison with the water balance results and the competing MOD16A2 method. An important component of water balance is the retention change $(\Delta S)$ in the catchment. In this study, the $\Delta S$ values were determined on the basis of water table observations. This allowed for estimation of underground retention.

Water table changes between the beginning and the end of particular hydrological years $(\Delta h)$ indicate a significant reduction in aquifer storage in 2014 and 2015 (negative values) (Fig. 5). The highest $\Delta h$ was obtained for 2014 . It reached a mean of $-1.30 \mathrm{~m}$ (near watersheds) and $-0.75 \mathrm{~m}$ (in river valleys). The driest year in the entire study interval (2015) was characterised by much lower $\Delta h$ values between the end and the beginning of the balance interval compared to 2014 (with a mean of $-0.47 \mathrm{~m}$ near watersheds and $-0.23 \mathrm{~m}$ in river valleys). In 2016, the values of differences in the water table positions were positive at all measurement points. This indicates an increase in underground retention in the first aquifer, caused by dominance of recharge over loss which resulted from river drainage and evapotranspiration. As in earlier years, the largest differences were observed near watersheds. The mean difference of water table for these areas was $0.73 \mathrm{~m}$. In the case of river valleys, the mean $\Delta h$ reached $0.35 \mathrm{~m}$.

The average $\Delta S$, recalculated to water column in $\mathrm{mm}$, for the area of both catchments, reached $124 \mathrm{~mm}$ in 2014 and $-60 \mathrm{~mm}$ in 2015 . This volume could be removed from the system by river drainage and evaporation. Both evapotranspiration and river discharge are values included in the catchment hydrological balance. Therefore, the approximate assessment of the calculated $E T_{a}$ reliability in years with groundwater deficiency was based on the assumption that it should correspond to the difference between precipitation and river discharge. The opposite case occurred in 2016 . The volume of water stored within the aquifer was higher. The product of $\Delta h$ and $\mu$ for the 2016 balance year was $87 \mathrm{~mm}$ on average for both catchments. 
[mu] aWs

음

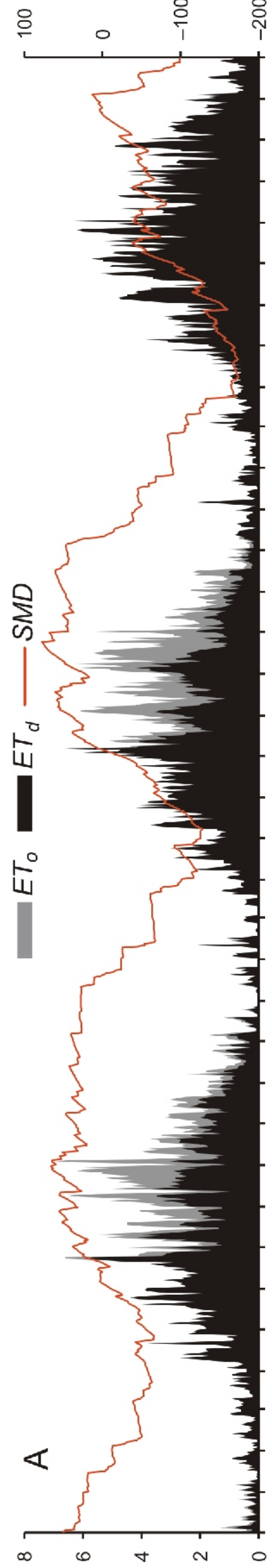

$[$ Кер/mu] $\perp \exists$

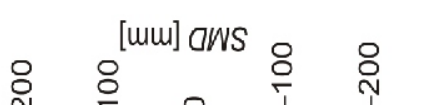
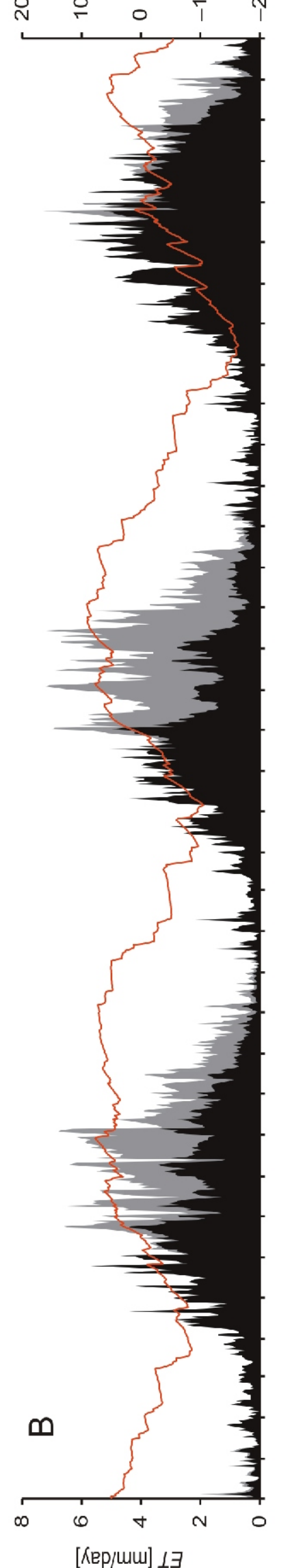

$(-) \stackrel{11}{ } \perp \exists$

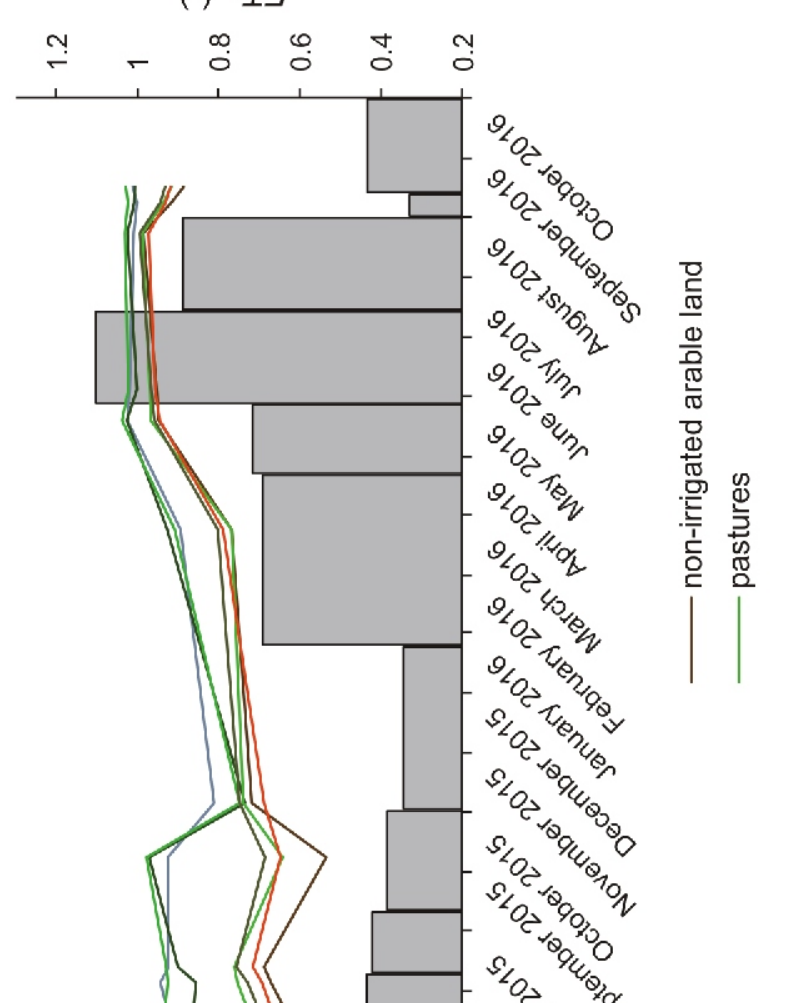

뜽ํำ

范

혼

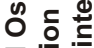

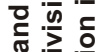

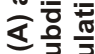

采

중 둥

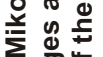

更

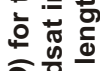

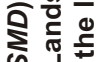

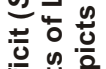

送造

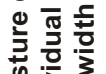

능 궁

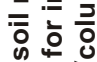

홍이

응

近

응

$2 / 1 / 2 / 3 / 2$

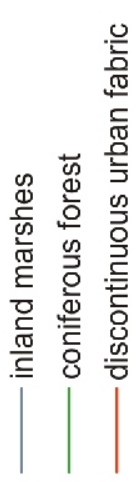

능

की ठ․

든

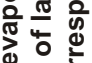

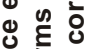

远

๘

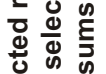

흔

0 ₹ 3

숭봉

幽。

응 웅

힌

흥 응

粕

후응을

응

己े 잉

\&

बे

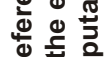

능

ㄷㅇㅇ

은.

을

ठํ ษ

ले i⿱宀

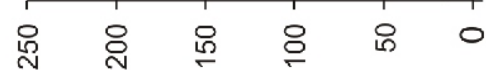
[um] pouəd ${ }_{\perp \exists}$ 


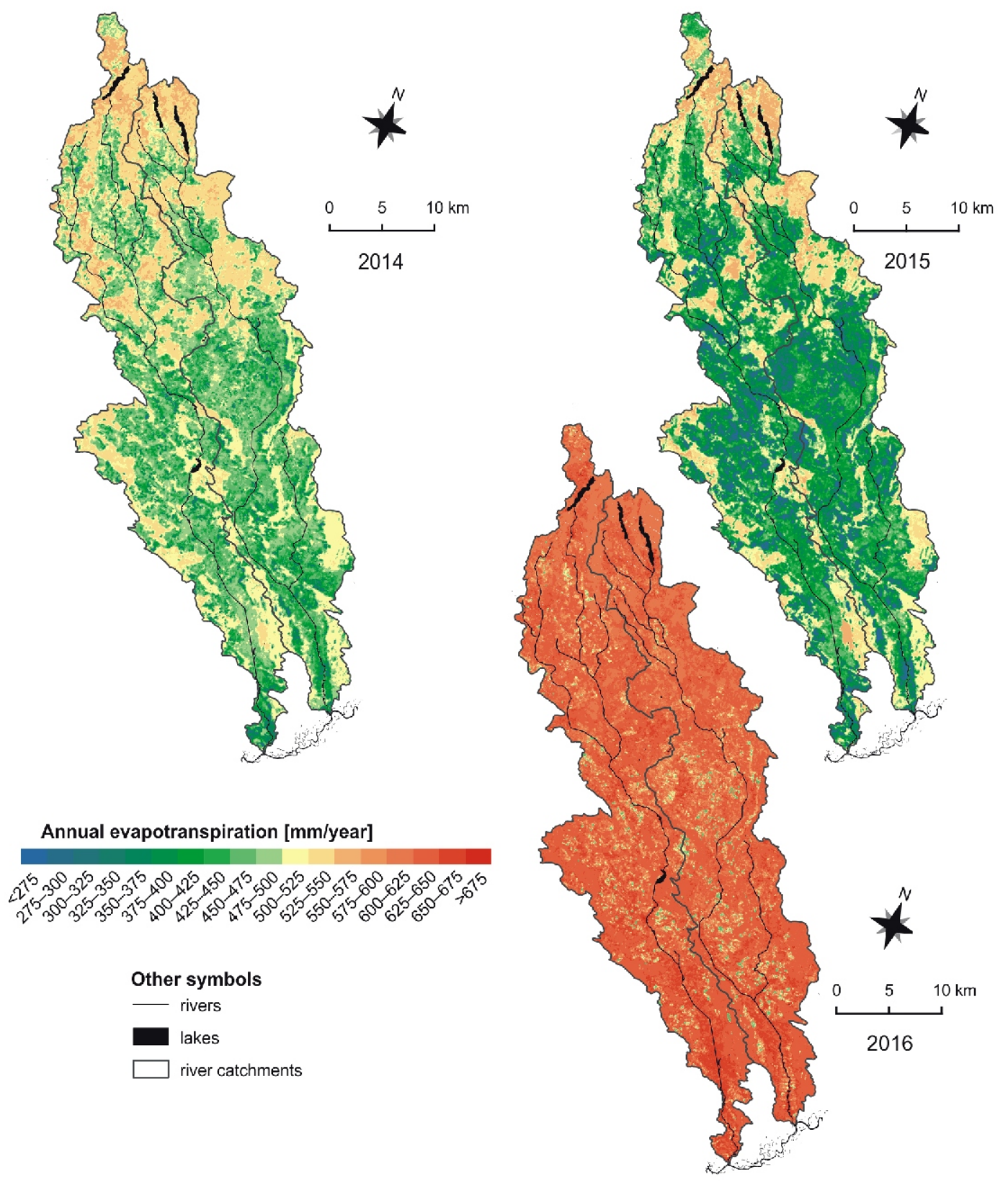

Fig. 4. Computed spatial distribution of annual evapotranspiration for the mSSEBop algorithm

Based on the water balance components, the mean evapotranspiration value was assessed for the catchments studied; this value was compared directly with the results obtained from the SSEBop model (Table 4).

In both catchments, the values of annual evapotranspiration (spatial averaging) calculated using the water balance and mSSEBop methods were similar (Table 4). The smallest differences were obtained for 2014. The differences reached $12 \mathrm{~mm} /$ year (Szkwa catchment) and $9 \mathrm{~mm} /$ year (Rozoga catchment). 2014 was the year in which the largest number of Landsat image sets was used in the calculations. Larger differences were noted in 2015. In this case the calculated $E T_{\text {a }}$ value was by $20 \mathrm{~mm} /$ year (Szkwa catchment) and $28 \mathrm{~mm} /$ year (Rozoga catchment) lower than the value resulting from water balance considerations. The largest differences between both methods were noted for 2016 . These partly resulted from changes in humidity of the vadose zone, which were not included in balance calculations.

In 2014 and 2015, the original SSEBop method returned results significantly different from the water balance values. The differences between SSEBop and water balance were largest in 2014. The average values of evapotranspiration for the entire area in the case of SSEBop were $218 \mathrm{~mm}$ higher than calculated using water balance. The differences in 2015 and 2016 reached 98 and $42 \mathrm{~mm}$. In the wet year $2016 E T_{a}$ values for SSEBop and mSSEBop methods were very similar - the differences reached only $16 \mathrm{~mm}$.

In 2014 and 2015, SSEBop ET for forest communities was higher than mSSEBop values, by 289 and $180 \mathrm{~mm} /$ year respectively. Values of differences for farmlands in 2014 reached 


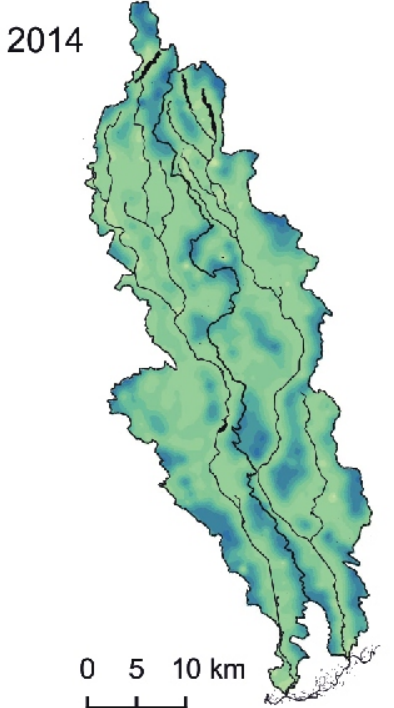

$\Delta h[\mathrm{~m}]$
$\square<-1.8 \quad \square-1.4--1.2 \square$
$\square-1.8--1.6 \square-1.2--1 \square$
$\square-1.6--1.4 \square-1--0.8 \square$
2015

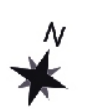

2015

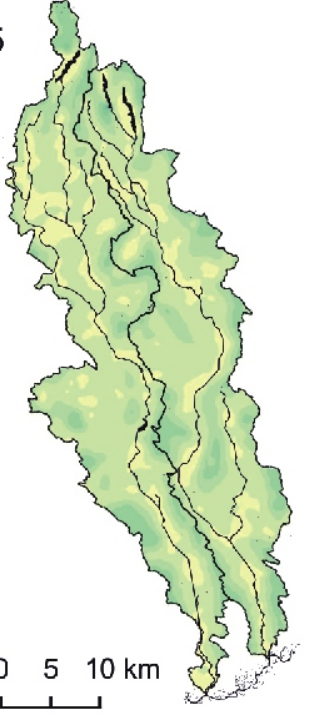

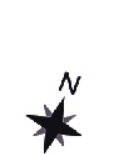

2016

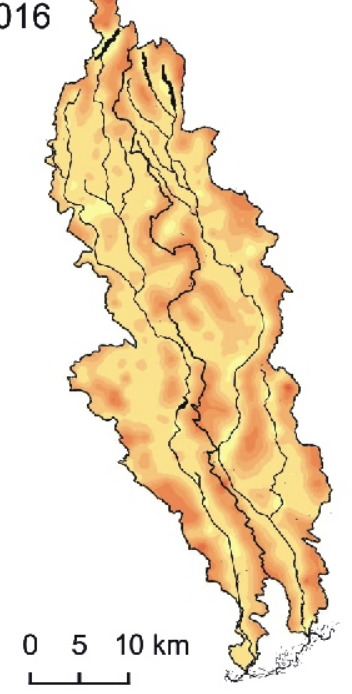

$\stackrel{N}{2}$

Fig. 5. Spatial distribution of differences in the water table level $(\Delta h)$ in hydrological years 2014-2016

$176 \mathrm{~mm} /$ year on average. Differences for 2015 were lower in comparison to the previous year and reached $68 \mathrm{~mm} / \mathrm{year}$. Evapotranspiration values calculated in 2016 using SSEBop were similar to those obtained using mSSEBop. For agricultural lands, the differences were in the range 15-23 mm/year (average for agricultural areas $-20.3 \mathrm{~mm} /$ year). In the case of forest habitats, they were clearly lower and averaged $4.5 \mathrm{~mm} /$ year.

Comparing the MOD16A2, SSEBop and mSSEBop methods, one should pay attention to the main similarities and differences between these models. As in the case of SSEBop/ mSSEBop, MOD16A2 uses remote sensing data and their derivatives, which allow calculation of the radiation balance (surface albedo in both algorithms) and determine the condition and degree of land coverage by vegetation (Leaf Area Index and Fraction of Absorbed Photosynthetically Active Radiation MOD16A2, NDVI - SSEBop/mSSEBop). In contrast to
SSEBop/mSSEBop, MOD16A2 does not use satellite thermal data, but is constructed based on an enhanced calculation algorithm, using, as for SSEBop/mSSEBop, the modified Penman-Monteith equation. In the MOD16A2 algorithm, total evapotranspiration is calculated as the sum of evaporation from the humid plant surface $\left(\lambda E_{\text {wet } c}\right)$, transpiration from the dry plant surface ( $\left.\lambda E_{\text {trans }}\right)$, and evaporation from the soil surface $\left(\lambda E_{\text {SOIL }}\right)$ :

$$
\lambda E=\lambda E_{\text {wet_c }}+\lambda E_{\text {soll }}
$$

The distinct characteristics of particular $E T_{a}$ components in MOD16A2 clearly separates this algorithm from the SSEBop/mSSEBop models, in which the influence of evaporation from the soil surface, and plant evaporation and transpiration, are determined jointly using the $E T_{f r}$ index.

Water budget results for the Szkwa and Rozoga catchments

\begin{tabular}{|c|c|c|c|c|c|c|c|c|c|c|c|c|}
\hline \multirow{3}{*}{$\begin{array}{l}\text { River catchment } \\
\text { Year } \\
\text { Balance elements }\end{array}$} & \multicolumn{6}{|c|}{ Szkwa } & \multicolumn{6}{|c|}{ Rozoga } \\
\hline & \multicolumn{2}{|c|}{2014} & \multicolumn{2}{|c|}{2015} & \multicolumn{2}{|c|}{2016} & \multicolumn{2}{|c|}{2014} & \multicolumn{2}{|c|}{2015} & \multicolumn{2}{|c|}{2016} \\
\hline & In & Out & In & Out & $\ln$ & Out & $\ln$ & Out & In & out & In & Out \\
\hline$P_{\text {kor }}$ & 601 & & 587 & & 873 & & 598 & & 598 & & 874 & \\
\hline$\Delta S$ & & & & & & 90 & & & & & & 84 \\
\hline$Q$ & & 128 & & 88 & & 110 & & 116 & & 90 & & 109 \\
\hline$E T=\ln -$ Out & \multicolumn{2}{|c|}{473} & \multicolumn{2}{|c|}{499} & \multicolumn{2}{|c|}{673} & \multicolumn{2}{|c|}{482} & \multicolumn{2}{|c|}{508} & \multicolumn{2}{|c|}{681} \\
\hline SSEBop $E T_{a}$ & \multicolumn{2}{|c|}{691} & \multicolumn{2}{|c|}{577} & \multicolumn{2}{|c|}{639} & \multicolumn{2}{|c|}{702} & \multicolumn{2}{|c|}{578} & \multicolumn{2}{|c|}{639} \\
\hline mSSEBop $E T_{a}$ & \multicolumn{2}{|c|}{461} & \multicolumn{2}{|c|}{479} & \multicolumn{2}{|c|}{622} & \multicolumn{2}{|c|}{473} & \multicolumn{2}{|c|}{480} & \multicolumn{2}{|c|}{625} \\
\hline
\end{tabular}

$P_{\text {kor. }}$ - corrected precipitation; $\Delta S$ - change in storage; $Q$ - river outflow (all values in $\mathrm{mm} / \mathrm{year}$ ) and its comparison to the values of evapotranspiration calculated by the SSEBop and mSSEbop algorithms 


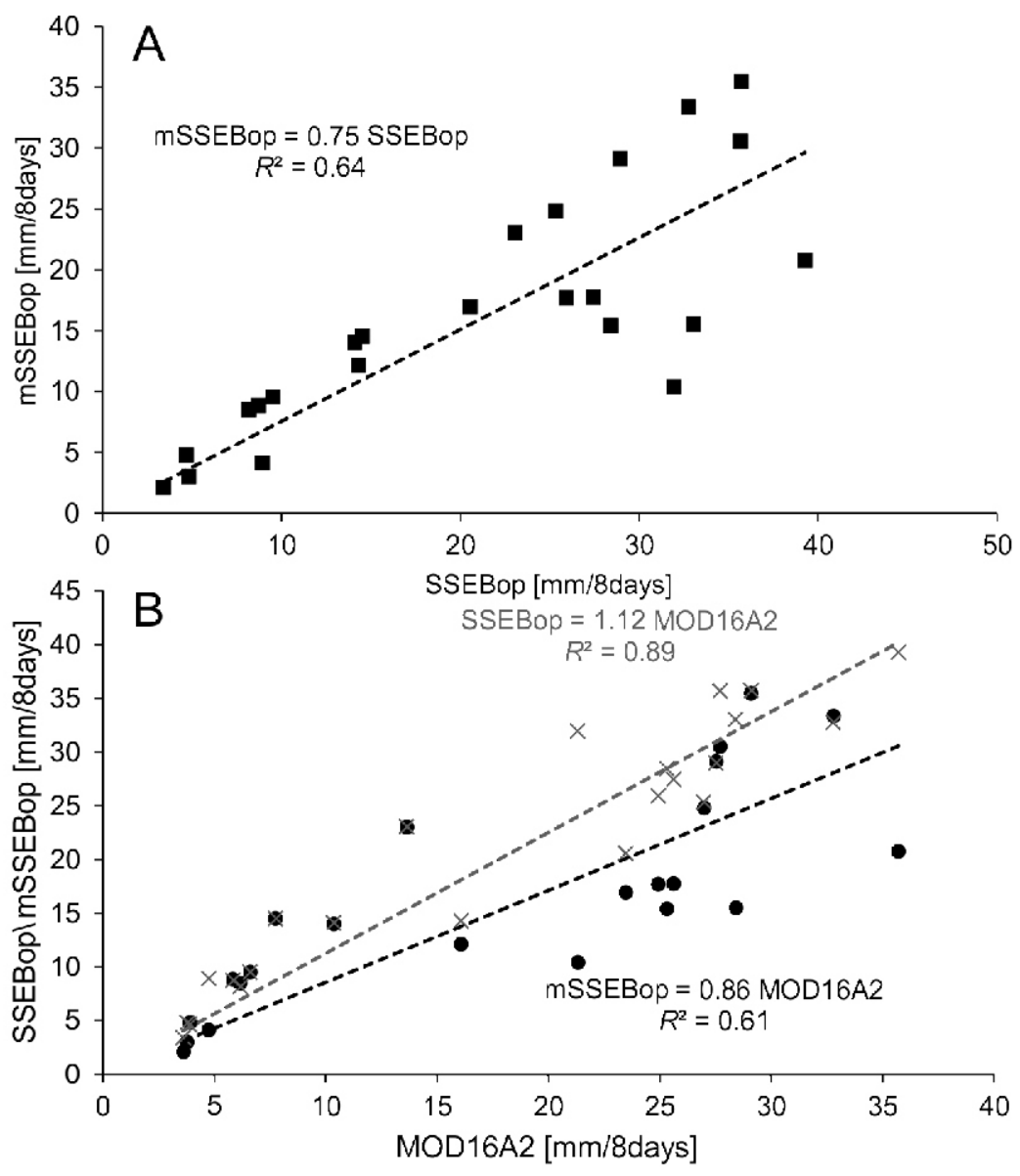

Fig. 6. Spatial mean results of $E T$ obtained with the SSEBop method versus the mSSEBop algorithm (A) and the SSEBop (grey crosses)/mSSEBop (black dots) algorithms versus MOD16A2 data (B)

A significant difference between both algorithms is also the application of different methods for assessing the share of water in evapotranspiration. MOD16A2 uses a function determining the available water resources, based on the complementary hypothesis in which the existence of a relation between surface humidity and air humidity is assumed. In the modified SSEBop algorithm, a model based on actual precipitation measurements and retention characteristics of subsurface sediments was applied.

Comparison of 8 days evapotranspiration sums for the study area (Fig. 6A) has indicated that $E T_{a}$ values calculated with application of the mSSEBop method were on average lower than those obtained using the SSEBop model. The adapted linear function allowed determination of the difference at $\sim 25 \%$. The data obtained using the original SSEBop model were also higher than those calculated using MOD16A2 ( 12\%; Fig. $6 B)$. In contrast, mSEBop returned $E T_{a}$ values on average lower than did MOD16A2 ( 14\%) with a much smaller fit with MOD16A2.

The temporal distribution of $E T_{a}$ values for particular forms of land coverage and land use indicates that trends in $E T_{a}$ value changes are similar in all methods discussed (Fig. 7A-C). The largest similarity is for cold months (October, November, March) and for the humid year 2016.
The results obtained using the original SSEBop method show similarity with the data of MOD16A2, primarily in agricultural areas (Fig. 7A). Data obtained for forest and shrubby forms of coverage show a slight excess of evapotranspiration calculated by SSEBop over MOD16A2 (Fig. 7B). Mean bias error (MBE) values calculated for MOD16A2 and SSEBop are generally $<0$. MBE; values furthest from 0 were obtained for May 2014 and June and August 2015 (Fig. 8A). Conditions in which MBE exceeded the value of 0 (MOD16A2 values higher than SSEBop) occurred during the growing seasons, mainly in areas occupied by agriculture.

For the mSSEBop algorithm, distinct differences in $E T_{a}$ values are visible for summer seasons of 2014 and 2015. Regardless of the land coverage class, $E T_{a}$ calculated by mSSEBop is lower than in the MOD16A2 data. These differences, assessed by MBE, reach up to $23.2 \mathrm{~mm} / 8$ days (Fig. 8B). They correspond to the periods in which high $S M D$ values were estimated. (Fig. 2A, B). There are discrepancies in $E T_{a}$ values for spring periods i.e. March (MBE for the entire area $=-3.0 \mathrm{~mm} / 8$ days), April ( $-5.4 \mathrm{~mm} / 8$ days) and May $(-10.0 \mathrm{~mm} / 8$ days $)$ in 2014 and in April $(-8.8 \mathrm{~mm} / 8$ days) and June $(-3.5 \mathrm{~mm} / 8$ days $)$ in 2015 . This is visible particularly in the case of woodland communities (Fig. 7B). Results of mSSEBop calculations in these intervals are higher than those from MOD16A2. They fall into seasons in 

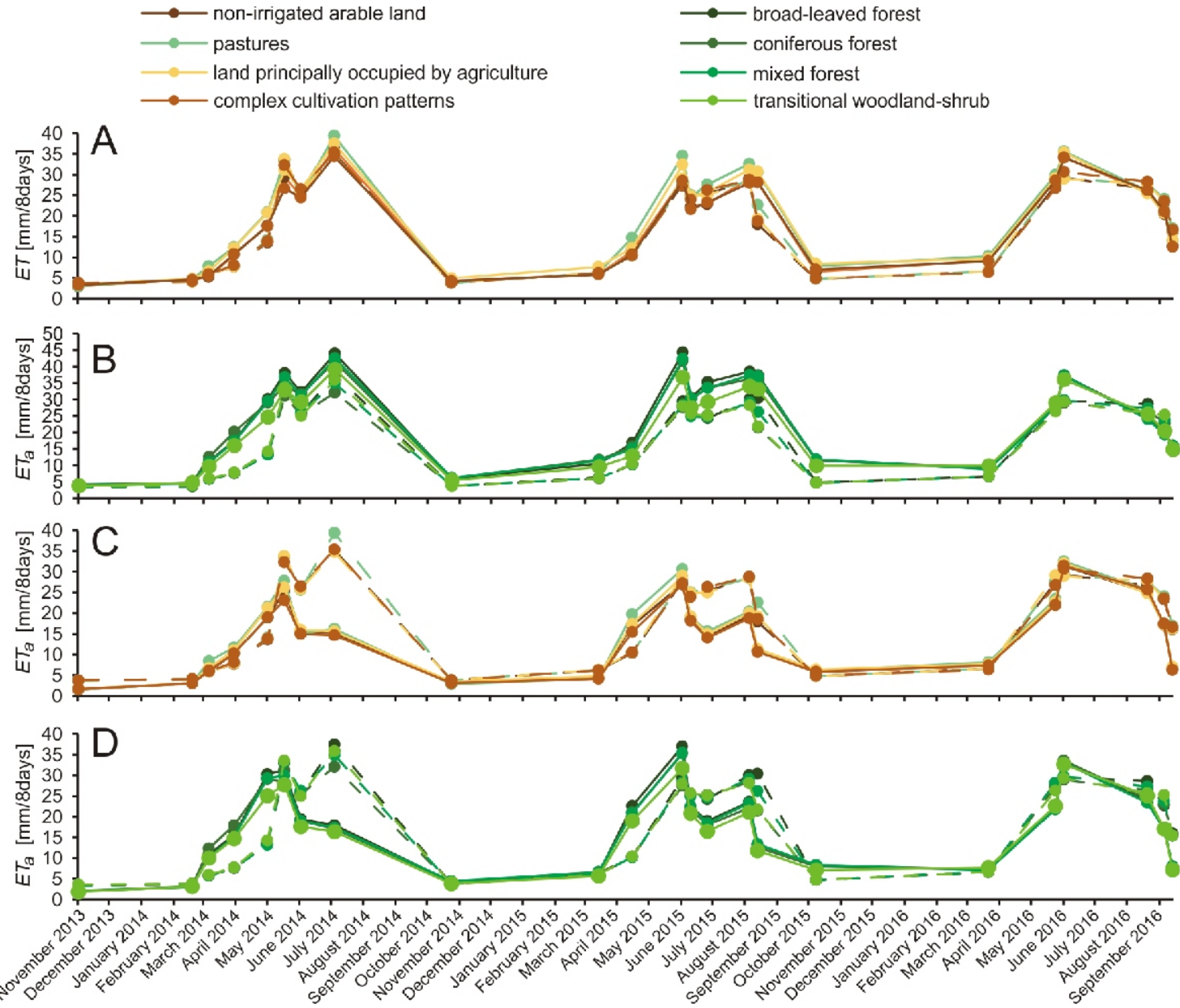

Fig. 7. Mean ET sums for agricultural (A, C) and woodland (B, D) land coverage classes for SSEBop (A, B), mSSEBop (C, D; solid lines) and MOD16A2 (dashed lines)

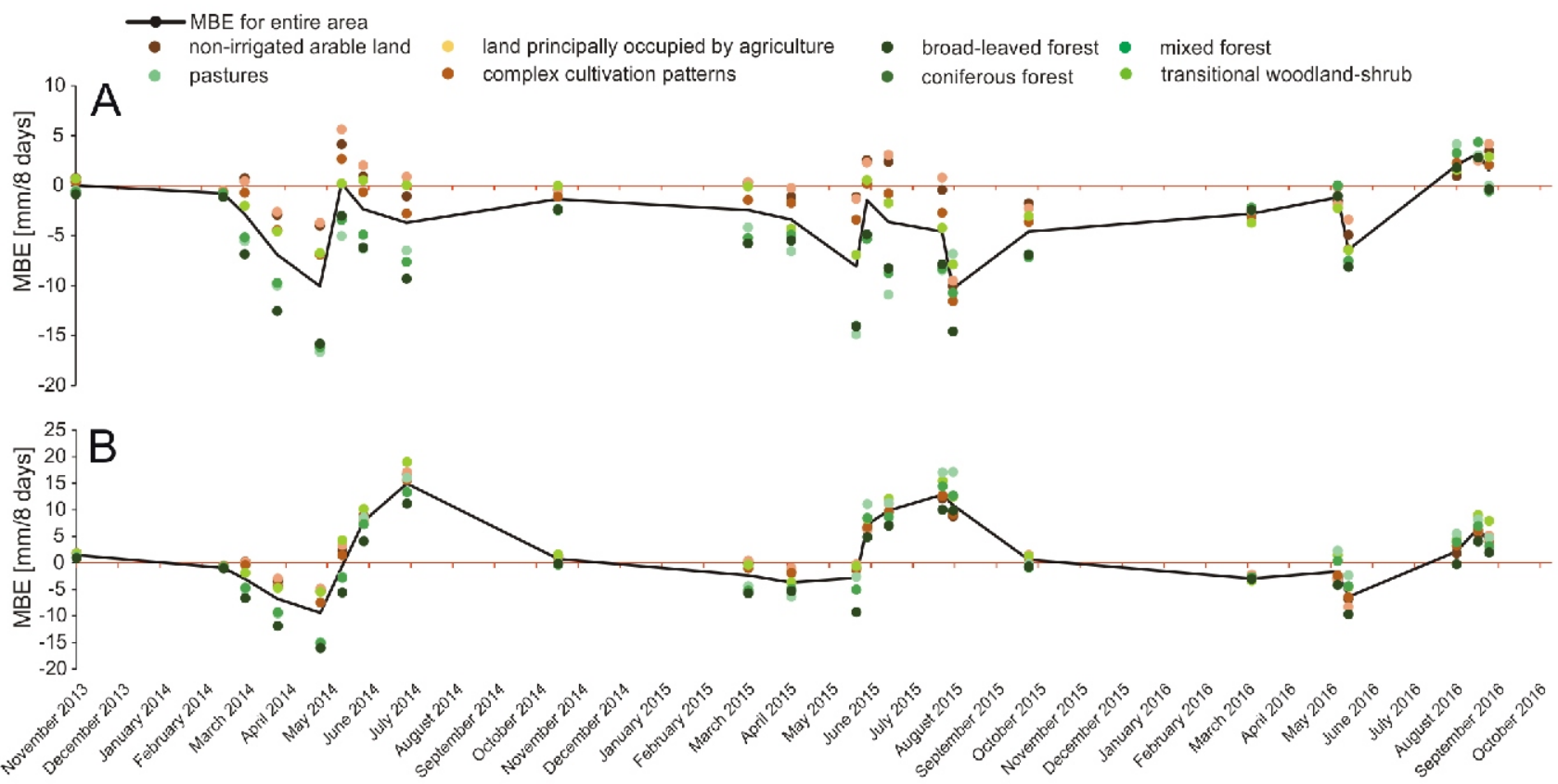

Fig. 8. Temporal distribution of MBE ( $\mathrm{mm} / 8$ days) for SSEBop (A) and mSSEBop (B; in relation to MOD16A2 data) for selected CLC2012 classes and the entire study area 
which optimal humidity conditions (negative SMD values) and high $E T_{f r}$ values occur.

The results obtained for mSSEBop indicate that the highest impact on MBE values arise from quantitative changes of water content in soils and sub-surface deposits and spatial and temporal $E T_{\text {fr }}$ distribution. In the case of the first factor, positive MBE values resulted from the different methodology of using soil moisture. Spatial distributions of precipitation values and information on underground retention properties were used in this case in the mSSEBop algorithm. Simulations of surface moisture changes in MOD16A2 are based on values of air humidity and water vapour pressure deficit (sensitive e.g. to changes in air temperature and solar radiation;. Such estimation of substrate moisture (or lack thereof as in the case of SSEBop) may lead to overestimation of $E T_{a}$ values.

The second factor marks its influence particularly in woodland areas. $E T_{\text {fr }}$ indices calculated using SSEBop and mSSEBop favour the occurrence of higher $E T_{a}$ values than in the case of MOD16A2, particularly in the dry years 2014-2015 (Fig. 3C). Evapotranspiration combines two components transpiration and evaporation from humid surfaces. The first component is higher for areas with a prevalence of meadow vegetation and agrocoenoses, whereas the second is more significant for woodlands. Due to the larger leaf intercepting surface, the evaporation water was higher in woodlands in comparison to areas with different vegetation. Moreover, the factor influencing high $E T_{a}$ values for woodlands was the root zone depth, allowing forests to drain humidity from a larger depth range than in the case of meadow communities or crops.

Results obtained with application of the method proposed may be considered as reliable. This is supported by the significant concordance of average $E T_{a}$ values calculated for river catchments with the water balance results, as well as by qualitative similarity between mSSEBop and MOD16A2 values. It should be emphasised that results of $E T_{a}$ calculations referred to an area located in a climate zone which is characterised by high frequency of unfavourable (for satellite imaging) atmospheric conditions, and thus restricted access to Landsat data. The advantage of the mSSEBop over the water balance and MOD16A2 is its spatial resolution. This allows $E T_{a}$ distribution analyses to be made on a regional scale and also studies of smaller regions. Moreover, the range of input data is easily accessible and largely free of charge, which increases the applicability of the method.

\section{CONCLUSIONS}

The method of assessing evapotranspiration described is a multiproxy analysis and focuses on the main factors shaping its distribution. The proposed calculation procedure allows the inclusion of climatic and hydrological factors and of variations in vegetation coverage. Obtained from satellite remote sensing, instantaneous values of variables characterising the natural environment allow acquisition of information on the seasonal vari- ability of factors determining $E T_{a}$. The spatial resolution of the results obtained allows for analysis of $E T_{a}$ distribution both on regional and local scales.

Comparative analysis has shown that results obtained with the proposed method are reliable. There is a large concordance between evapotranspiration calculated with application of satellite images and expected values resulting from the catchment water balance. The results obtained using the original SSEBop method were less consistent with the results of water balance in the dry years 2014 and 2015 than mSSEBop outputs. In 2016 the values of both methods were similar.

A comparison of the results of $E T_{a}$ calculations using mSSEBop and MOD16A2 indicates a qualitative similarity between both data sets. High MOD16A2 values correspond to high $E T$ values calculated using mSSEBop. Greater differences occur during dry periods (2014 and 2015), in which the effect of soil moisture decrease on $E T_{a}$ values intensifies. In 2016, when the correction due to soil moisture was the lowest, $E T_{a}$ values for mSSEBop, MOD16As and SSEBop are similar.

Restrictions in the application of the method presented are linked with the low temporal resolution of the available satellite material, acquired in optical bands and thermal infrared, particularly in areas located in mid latitudes. This results from the long revisit times for satellites imaging at high spatial resolutions, and their sensitivity to cloudiness and fogging. This fact considerably complicates the analyses for cold periods, in which the frequency of unfavourable meteorological conditions is the largest. Finally, results obtained for the autumn-winter season are less reliable. This unreliability may be restricted by application of atmospheric correction of satellite images, however in the case of strong cloudiness the possibility of acquiring useful surface images remains restricted. These problems may be alleviated by the development of remote sensing techniques and increased frequency of satellite revisits. The Sentinel series satellite mission of the European Cosmic Agency seems promising in this context. The introduction of Sentinel $2 \mathrm{~A}$ and $\mathrm{B}$ and Sentinel 3 satellites into orbit in 2015, 2016 and 2017 allow for acquisition of multispectral images with temporal resolution not exceeding 5 days. The temporal resolution of data used in $E T_{a}$ analyses can also be increased by including data from observations carried out using meteorological satellites belonging to the European Organisation for the Exploitation of Meteorological Satellites (EUMETSAT). Despite the low spatial resolution of meteorological satellites (from several to several tens of kilometres depending on the sensors used), they enable 24-hour monitoring of temperature and humidity in the atmospheric profile as well as the energy balance.

Regardless of these limitations, the method presented gives promising results. The studies performed have shown that, despite unfavourable climate conditions, algorithms based on satellite data are an encouraging group of methods that allow estimation of evapotranspiration in mid latitudes.

Acknowledgements. The authors would like to thank the Reviewers: E. Woźniak and M. Kępińska-Kasprzak for their time and effort in reviewing the paper. 


\section{REFERENCES}

Adane, Z.A., Nasta, P., Zlotnik, V., Wedin, D., 2018. Impact of grassland conversion to forest on groundwater recharge in the Nebraska Sand Hills. Journal of Hydrology: Regional Studies, 15: 171-183.

Allen, R.G., Pereira, L.S., Raes, D., Smith, M., 1998. Crop evapotranspiration?: Guidelines for computing crop water requirements. Food and Agriculture Organization of the United Nations. Rome, Italy.

Bentkowski, A., 2000. Objaśnienia do Mapy Hydrogeologiczne polski, skala 1:50 000, arkusz Spychowo (217) (in Polish) Państwowy Instytut Geologiczny, Warszawa.

Biggs, T.W., Petropoulos, G.P., Velpuri, N.M., Marshall, M., Glenn, E.P., Nagler, P., Messina, A., 2015. Remote sensing of evapotranspiration from croplands. In: Remote Sensing Handbook, 3: Remote Sensing of Water Resources, Disasters, and Urban Studies (ed. P.S. Thenkabail): 59-99. CRC Press. Boca Raton, USA.

Bogacki, M., 1969. The dunes of the Kurpie Plain (in Polish with English summary). In: Dune Processes and Forms in Poland (ed. R. Galon): 327-354. Państwowe Wydawnictwo Naukowe PWN, Warszawa.

Bouchet, R.J., 1963. Evapotranspiration reelle, evapotranspiration potentielle, et production agricole. Annales Agronomae, 14: 743-824.

Budzyńska, M., Dąbrowska-Zielińska, K., Turlej, K., Małek, I. Bartold, M., 2011. Monitoring of the Biebrza wetlands using remote sensing methods (in Polish with English summary). Water-Environment-Rural Areas, 11: 39-64.

Chen, M., Senay, G.B., Singh, R.K., Verdin, J.P., 2016. Uncertainty analysis of the Operational Simplified Surface Energy Balance (SSEBop) model at multiple flux tower sites. Journal of Hydrology, 536 : 384-399.

Ćwiertniewska, Z., Herbich, P., 2002. Objaśnienia do Mapy Hydrogeologicznej Polski, skala 1:50 000, arkusz Świętajno (in Polish). Państwowy Instytut Geologiczny, Warszawa.

Dąbrowska-Zielińska, K., 1995. Assesment of evapotranspiration, soil moisture and green biomass of grassland using NOAA satellite images (in Polish with English summary). Continuo, Wrocław.

Dębski, K., 1970. Hydrologia (in Polish). Arkady, Warszawa.

Di, S.C., Li, Z.L., Tang, R., Wu, H., Tang, B.H., Lu, J., 2015. Integrating two layers of soil moisture parameters into the MOD16 algorithm to improve evapotranspiration estimations. International Journal of Remote Sensing, 36: 4953-4971.

Dingman, S.L., 2015. Evapotranspiration. In: Physical Hydrology, 3rd ed. (ed. S.L. Dingman): 272-324. Prentice Hall, Long Grove, USA.

Ershadi, A., Mccabe, M.F., Evans, J.P., Walker, J.P., 2013. Remote Sensing of Environment Effects of spatial aggregation on the multi-scale estimation of evapotranspiration. Remote Sensing of Environment, 131: 51-62.

Fisher, J.B., Tu, K.P., Baldocchi, D.D., 2008. Global estimates of the land-atmosphere water flux based on monthly AVHRR and ISLSCP-II data, validated at 16 FLUXNET sites. Remote Sensing of Environment, 112: 901-919.

Glejch, M., 2000. Objaśnienia do Mapy Hydrogeologicznej Polski, skala 1:50 000, arkusz Myszyniec (255) (in Polish). Państwowy Instytut Geologiczny, Warszawa.

Glenn, E.P., Neale, C.M.U., Hunsaker, D.J., Nagler, P.L., 2011. Vegetation index-based crop coefficients to estimate evapotranspiration by remote sensing in agricultural and natural ecosystems. Hydrological Processes, 25: 4050-4062.

Hoffmann, J., Sander, P., 2007. Remote sensing and GIS in hydrogeology. Hydrogeology Journal, 15: 1-3.

Hulboj, A., 2002. Objaśnienia do Mapy Hydrogeologicznej Polski, skala 1:50 000, arkusz Ostrołęka (333) (in Polish). Państwowy Instytut Geologiczny, Warszawa.
Jaworski, J., 2004. Evaporation in the hydrological cycle of river basin (in Polish with English summary). Polskie Towarzystwo Geofizyczne, Warszawa.

Jensen, M.E., Burman, R.D., Allen, R.G.,1990. Evapotranspiration and Irrigation Water Requirements. ASCE Manuals and Reports on Engineering Practice No. 70. American Society of Civil Engineers. New York, USA

Khalaf, A., Donoghue, D., 2012. Estimating recharge distribution using remote sensing: A case study from the West Bank. Journal of Hydrology, 414-415 : 354-363.

Kozłowska, M., Kozłowski, I., 1996. Objaśnienia do Szczegółowe Mapy Geologicznej Polski, skala 1:50 000, arkusz RucianeNida (218) (in Polish). Państwowy Instytut Geologiczny, Warszawa.

Li, R., Min, Q., Lin, B., 2009. Estimation of evapotranspiration in a mid-latitude forest using the Microwave Emissivity Difference Vegetation Index (EDVI). Remote Sensing of Environment, 113: 2011-2018.

Liou, Y.A., Kar, S.K., 2014. Evapotranspiration estimation with remote sensing and various surface energy balance algorithms a review. Energies, 7: 2821-2849.

Lu, J., Sun, G., McNulty, S.G., Amatya, D.M. ,2005. A comparison of six potential evapotranspiration methods for regional use in the southeastern United States. Journal of the American Water Resources Association, 41: 621-633.

Matuszkiewicz, M.J., Solon, J., Kowalska, A., Wolski, J., Affek, A., Degórski, M., Grabińska, B., Kozłowska, A., Plit, J., Pawlicki, R.W., 2017. Long-term forest cover changes in terms of landscape sustainability: a case of Masuria-Kurpie borderland (in Polish with English summary). IGiPZ PAN, Warszawa.

McCabe, M.F., Wood, E.F., 2006. Scale influences on the remote estimation of evapotranspiration using multiple satellite sensors. Remote Sensing of Environment, 105: 271-285.

Mu, Q., Zhao, M., Running, S.W., 2011. Remote Sensing of Environment Improvements to a MODIS global terrestrial evapotranspiration algorithm. Remote Sensing of Environment, 115: 1781-1800.

Nouri, H., Beecham, S., Anderson, S., Hassanli, A.M., Kazemi, F., 2015. Remote sensing techniques for predicting evapotranspiration from mixed vegetated surfaces. Urban Water Journal, 12: 380-393.

Nowicki, Z., 2000. Objaśnienia do Mapy Geologicznej Polski, skala 1:50 000, arkusz Kadzidło (in Polish). Państwowy Instytut Geologiczny, Warszawa.

Richter, R., Schläpfer, D., 2016. Atmospheric/Topographic Correction for Satellite Imagery (ATCOR-2/3 User Guide, Version 9.0.2). ReSe Applications Schläpfer. Wil, Switzerland.

Roy, D.P., Kovalskyy, V., Zhang, H.K., Vermote, E.F., Yan, L., Kumar, S.S., Egorov, A., 2016. Characterization of Landsat-7 to Landsat-8 reflective wavelength and normalized difference vegetation index continuity. Remote Sensing of Environment, 185: $57-70$

Running, S. W., Mu, Q., Zhao, M., Moreno, A., 2019. User's Guide. MODIS Global Terrestrial Evapotranspiration ( ET ) Product NASA Earth Observing System MODIS Land Algorithm, Washington DC, USA.

Schulte, R.P.O., Diamond, J., Finkele, K., Holden, N.M., Brereton, A.J., 2005. Predicting the soil moisture conditions of Irish grasslands. Irish Journal of Agricultural and Food Research, $44:$ :95-110.

Senay, G.B., Bohms, S., Singh, R.K., Gowda, P.H., Velpuri, N.M., Alemu, H., Verdin, J.P., 2013. Operational evapotranspiration mapping using remote sensing and weather datasets: a new parameterization for the SSEB approach. Journal of the American Water Resources Association, 49: 577-591.

Senay, G.B., Friedrichs, M., Singh, R.K., Velpuri, N.M., 2016. Evaluating Landsat 8 evapotranspiration for water use mapping in the Colorado River Basin. Remote Sensing of Environment, 185: $171-185$ 
Seneviratne, S.I., Corti, T., Davin, E.L., Hirschi, M., Jaeger, E.B., Lehner, I., Orlowsky, B., Teuling, A.J., 2010. Investigating soil moisture-climate interactions in a changing climate: a review. Earth-Science Reviews, 99: 125-161.

Singh, R., Senay, G., 2015. Comparison of Four Different Energy Balance Models for Estimating Evapotranspiration in the Midwestern United States. Water, 8-9: 1-19.

Soczyńska, U. (ed.), 1989. Procesy hydrologiczne (in Polish). Państwowe Wydawnictwo Naukowe, Warszawa.

Stopa-Boryczka, M., Boryczka, J., Wawer, J., Grabowska, K., Dobrowolska, M., Osowiec, M., Błażek, E., Skrzypczuk, J., Grzęda, M., 2013. Klimat Północno-wschodniej Polski według podziału fizycznogeograficznego J. Kondrackiego i J. Ostrowskiego (in Polish). Wydział Geografii i Studiów Regionalnych, Warszawa.

Teuling, A.J., 2018. A forest evapotranspiration paradox investigated using lysimeter data. Vadose Zone Journal, 17: 1-7.

US Geological Survey, 2019. Landsat 8 (L8) Data Users Handbook (4th ed.) Sioux Falls, USA. https://www.usgs.gov/media/files/landsat-8-data-users-handbook
Velpuri, N.M., Senay, G.B., Singh, R.K., Bohms, S., Verdin, J.P., 2013. A comprehensive evaluation of two MODIS evapotranspiration products over the conterminous United States: Using point and gridded FLUXNET and water balance ET. Remote Sensing of Environment, 139: 35-49.

Wang, K., Dickinson, R.E., 2012. A review of global terrestrial evapotranspiration: Observation, modeling, climatology, and climatic variability. Reviews of Geophysics, 50: 1-54.

World Meteorological Organisation (WMO), 2008. Guide to Hydrological Practices: Volume I: Hydrology - from measurement to hydrological information (sixth edition). WMO Report No. 168 (Vol. I).

Zhang, L., Dawes, W.R., Walker, G.R., 2001. Response of mean annual evapotranspiration to vegetation changes at catchment scale. Water Resources Research, 37: 701-708.

Żuk, R., 1999. Objaśnienia do Szczegółowej Mapy Geologicznej Polski, skala 1:50 000, arkusz Świetajno (216) (in Polish). Ministerstwo Środowiska, Państwowy Instytut Geologiczny, Warszawa. 